Supporting Information for

Environ. Sci. Technol.

\title{
Export of Organic Carbon from Reduced Fine-Grained Zones Governs Biogeochemical Reactivity in Simulated Aquifer
}

\author{
Meret Aeppli ${ }^{1}$, Tristan Babey ${ }^{1}$, Maya Engel ${ }^{1,2}$, Emily M. Lacroix ${ }^{1}$, Bradley B. Tolar ${ }^{1}$, \\ Scott Fendorf ${ }^{1}$, John R. Bargar ${ }^{2}$, and Kristin Boye ${ }^{*, 2}$ \\ ${ }^{1}$ Department of Earth System Science, Stanford University, Stanford, California 94305, United \\ States \\ ${ }^{2}$ Geochemistry and Biogeochemistry Group, SLAC National Accelerator Laboratory, Menlo \\ Park, California 94025, United States \\ ${ }^{*}$ Corresponding author: \\ kboye@slac.stanford.edu \\ 21 Pages, 19 Figures, 6 Tables
}




\section{Contents}

S1 Sediment characterization 3

S2 Artificial groundwater 4

S3 Column system 4

S4 Mediated electrochemistry 5

S5 Results groundwater flow experiment $\quad 6$

$\begin{array}{lll}\text { S6 } & \text { Results end point sampling } & 11\end{array}$

S7 Mass balance calculations for organic carbon $\quad 15$

$\begin{array}{lll}\text { S8 } & \text { Microbial analysis } & 17\end{array}$

$\begin{array}{lll}\text { S9 } & \text { Mass balance calculations for iron } & 19\end{array}$

$\begin{array}{ll}\text { S10 Visual observations of changes in columns } & 21\end{array}$ 


\section{S1 Sediment characterization}

Table S1 Particle size distribution in sediments (lens material) from Wind River (data from Kumar et al. (1)) and Slate River used in the column experiments, as determined by U.S. standard sieve particle separation.

\begin{tabular}{ccc}
\hline Particle size fraction & Wind River sediment & Slate River sediment \\
\hline $1-2 \mathrm{~cm}$ (very coarse sand) & 0 & 2 \\
$0.5-1 \mathrm{~mm}$ (coarse sand) & 6 & 3 \\
$0.15-0.5 \mathrm{~mm}$ (medium to fine sand) & 33 & 9 \\
$0.053-0.15 \mathrm{~mm}$ (very fine sand) & 41 & 11 \\
$<0.053 \mathrm{~mm}$ (silt and clay) & 19 & 73 \\
\hline
\end{tabular}

Table S2 Elemental composition of the sediments from Wind River and Slate River, and ferrihydritecoated sand used in the column experiments.

\begin{tabular}{cccc}
\hline Element & $\begin{array}{c}\text { Wind River } \\
\text { sediment }\end{array}$ & $\begin{array}{c}\text { Slate River } \\
\text { sediment }\end{array}$ & $\begin{array}{c}\text { Ferrihydrite-coated } \\
\text { sand }\end{array}$ \\
\hline $\mathrm{C}(\mathrm{mg} / \mathrm{g})$ & $21.6 \pm 0.5$ & $39.6 \pm 0.1$ & $0.1 \pm 0.0$ \\
$\mathrm{Fe}(\mathrm{mg} / \mathrm{g})$ & $26.7 \pm 2.5$ & $33.0 \pm 1.5$ & $1.0 \pm 0.1$ \\
$\mathrm{Mn}(\mathrm{mg} / \mathrm{g})$ & $0.5 \pm 0.0$ & $0.4 \pm 0.0$ & $0.0 \pm 0.0$ \\
$\mathrm{~S}(\mathrm{mg} / \mathrm{g})$ & $3.8 \pm 0.1$ & $1.7 \pm 0.1$ & $0.5 \pm 0.7$ \\
$\mathrm{Si}(\mathrm{mg} / \mathrm{g})$ & $264.1 \pm 26.4$ & $301.2 \pm 27.4$ & $478.0 \pm 3.1$ \\
$\mathrm{Ca}(\mathrm{mg} / \mathrm{g})$ & $46.7 \pm 0.1$ & $12.0 \pm 0.0$ & $0.1 \pm 0.0$ \\
\hline
\end{tabular}




\section{S2 Artificial groundwater}

Table S3 Chemical composition of artificial groundwater based on the composition of groundwater at the Wind River site. Groundwater was prepared by adding the salts of the respective ions to doubly deionised water resulting in a $\mathrm{pH}$ of around 7.5 .

\begin{tabular}{ccc}
\hline Ion & Concentration $(\mathrm{mM})$ & $\mathrm{Salts}$ \\
\hline $\mathrm{HCO}_{3}^{-}$ & 2.9 & $\mathrm{NaHCO}_{3}$ \\
$\mathrm{Ca}^{2+}$ & 3.7 & $\mathrm{CaCl}$ \\
$\mathrm{Cl}^{-}$ & 16.9 & $\mathrm{NaCl}$ \\
$\mathrm{Na}^{+}$ & 104.4 & $\mathrm{Na}_{2} \mathrm{SO}_{4}$ \\
$\mathrm{Mg}^{2+}$ & 18.5 & $\mathrm{MgSO}_{4}$ \\
$\mathrm{~K}^{+}$ & 0.5 & $\mathrm{~K}_{2} \mathrm{SO}_{4}$ \\
$\mathrm{SiO}_{3}^{2-}$ & 0.3 & $\mathrm{Na}_{2} \mathrm{SiO}_{3} \cdot 9 \mathrm{H}_{2} \mathrm{O}$ \\
$\mathrm{NO}_{3}^{-}$ & 0.1 & $\mathrm{NaNO}_{3}$ \\
$\mathrm{SO}_{4}^{2-}$ & 62.5 & $\mathrm{Na}_{2} \mathrm{SO}_{4}, \mathrm{MgSO}_{4}, \mathrm{~K}_{2} \mathrm{SO}_{4}$ \\
\hline
\end{tabular}

\section{S3 Column system}
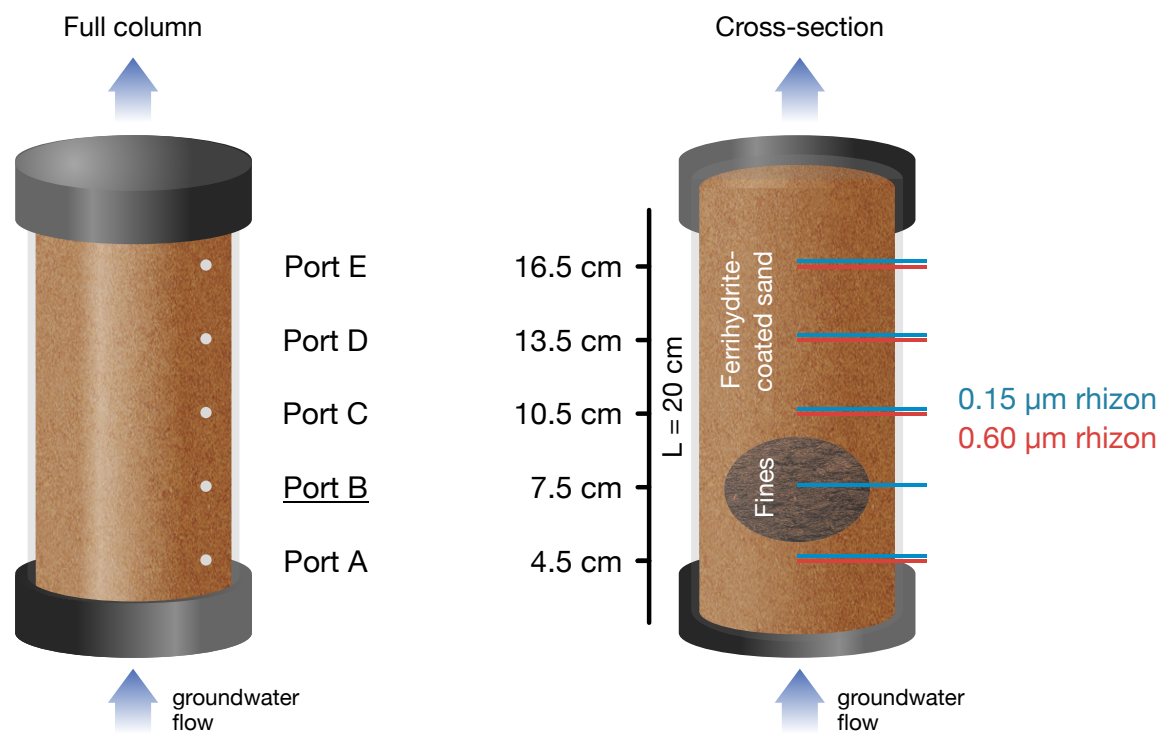

Figure S1 Setup and dimensions of the columns used herein. Full columns with ports A-E are shown on the left. The cross-section on the right shows the placement of the embedded fines in the ferrihydrite-coated sand and the rhizon samplers in the different ports. 


\section{S4 Mediated electrochemistry}

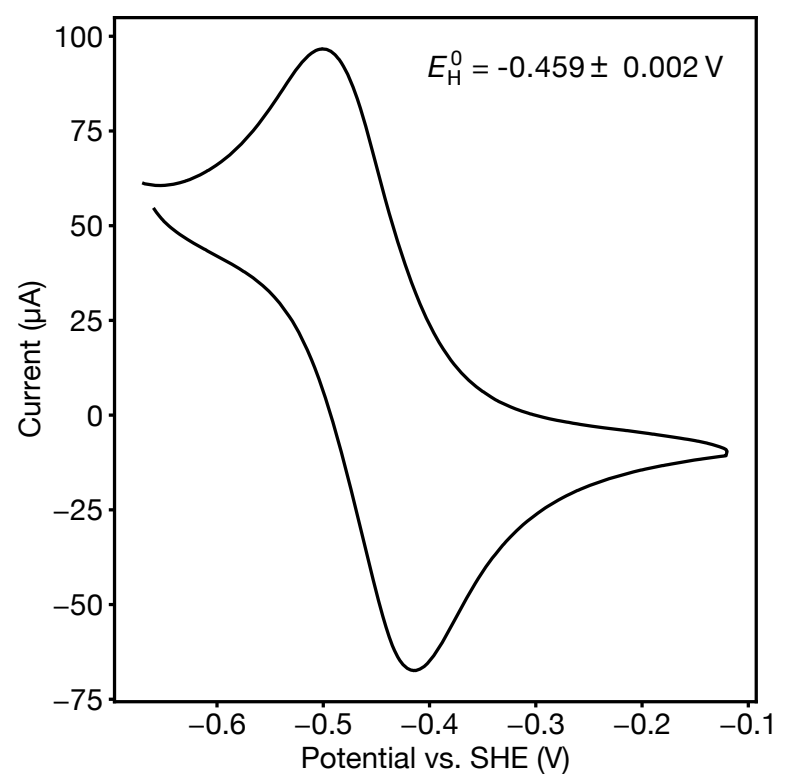

Figure S2 Exemplary cyclovoltammogram for the electron transfer mediator paraquat $\left(1,1^{\prime}\right.$ dimethyl-4,4'-bipyridinium). The potential on the $x$ axis is given versus the standard hydrogen electrode (SHE). The average standard reduction potential $\left(E_{\mathrm{H}}^{0}\right)$ of the compound and standard deviation of four measurements is given on the plot.

Table S4 Comparison between electron exchanging capacity (EEC) as determined using mediated electrochemistry and Fe contents determined using X-ray fluorescence on Wind River and Slate River fines, and ferrihydrite-coated sand in control columns (averages of six measurements each).

\begin{tabular}{lccc}
\hline Parameter & Wind River fines & Slate River fines & Control columns \\
\hline EEC $(\mathrm{mmol} / \mathrm{g})$ & $0.325 \pm 0.052$ & $0.447 \pm 0.084$ & $0.070 \pm 0.019$ \\
$\mathrm{Fe}(\mathrm{mmol} / \mathrm{g})$ & $0.412 \pm 0.036$ & $0.495 \pm 0.033$ & $0.064 \pm 0.018$ \\
\hline $\mathrm{Fe} / \mathrm{EEC}(-)$ & $1.28 \pm 0.13$ & $1.03 \pm 0.16$ & $1.01 \pm 0.44$ \\
\hline \hline
\end{tabular}




\section{S5 Results groundwater flow experiment}
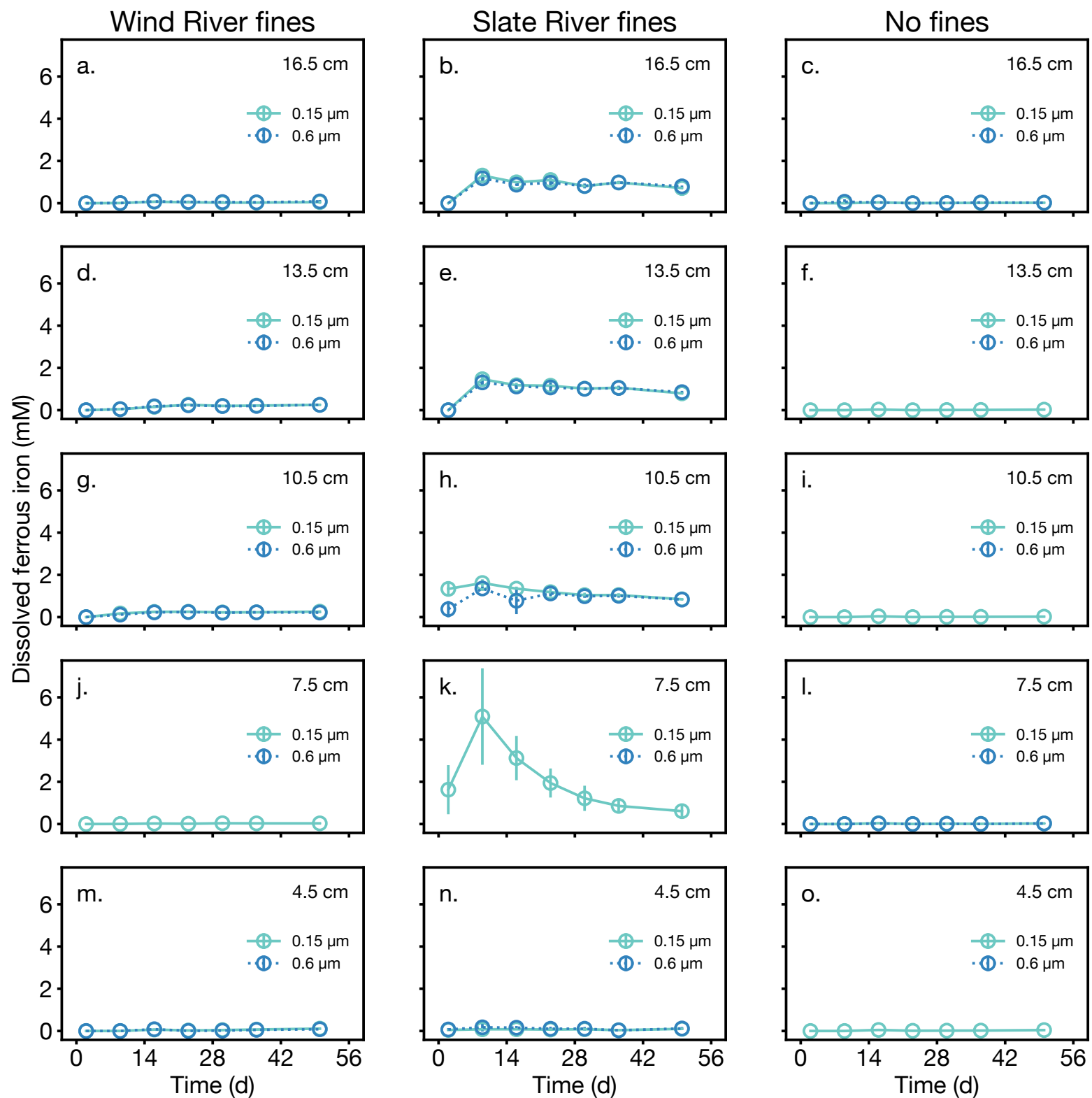

Figure S3 Dissolved ferrous iron concentrations during groundwater flow through columns with embedded lenses from Wind River (left) and Slate River (middle) and control columns without fines (right). Concentrations were determined on porewater extracted at $4.5-16.5 \mathrm{~cm}$ (lenses were located at $7.5 \mathrm{~cm}$ ) through rhizon samplers with mesh sizes of 0.15 and $0.60 \mu \mathrm{m}$. Error bars represent standard deviations between measurements on triplicate (Wind River and Slate River) duplicate (control) columns. 

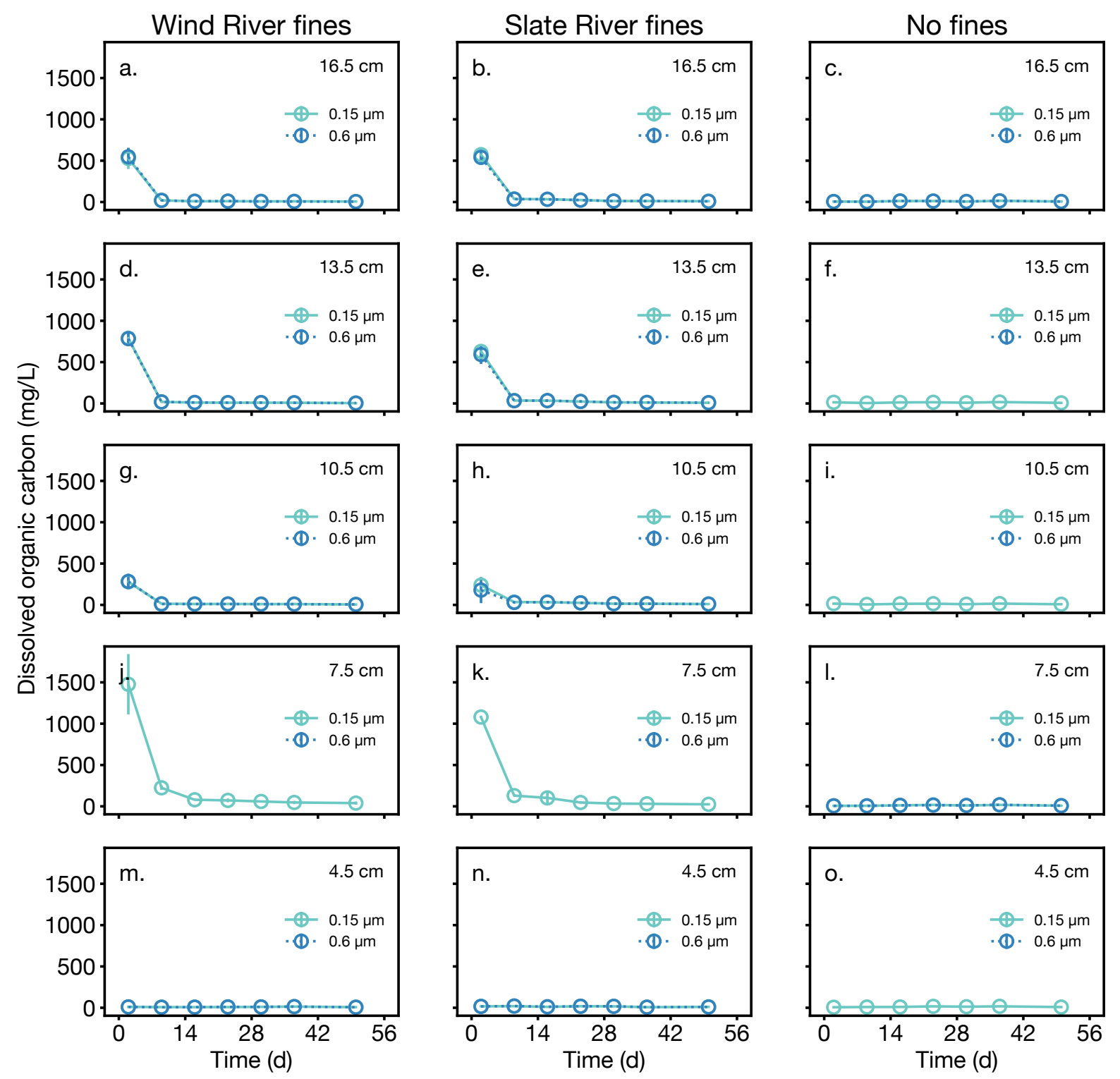

Figure S4 Dissolved organic carbon concentrations during groundwater flow through columns with embedded lenses from Wind River (left) and Slate River (middle) and control columns without fines (right). Concentrations were determined on porewater extracted at $4.5-16.5 \mathrm{~cm}$ (lenses were located at $7.5 \mathrm{~cm}$ ) through rhizon samplers with mesh sizes of 0.15 and $0.60 \mu \mathrm{m}$. Error bars represent standard deviations between measurements on triplicate (Wind River and Slate River) duplicate (control) columns. 

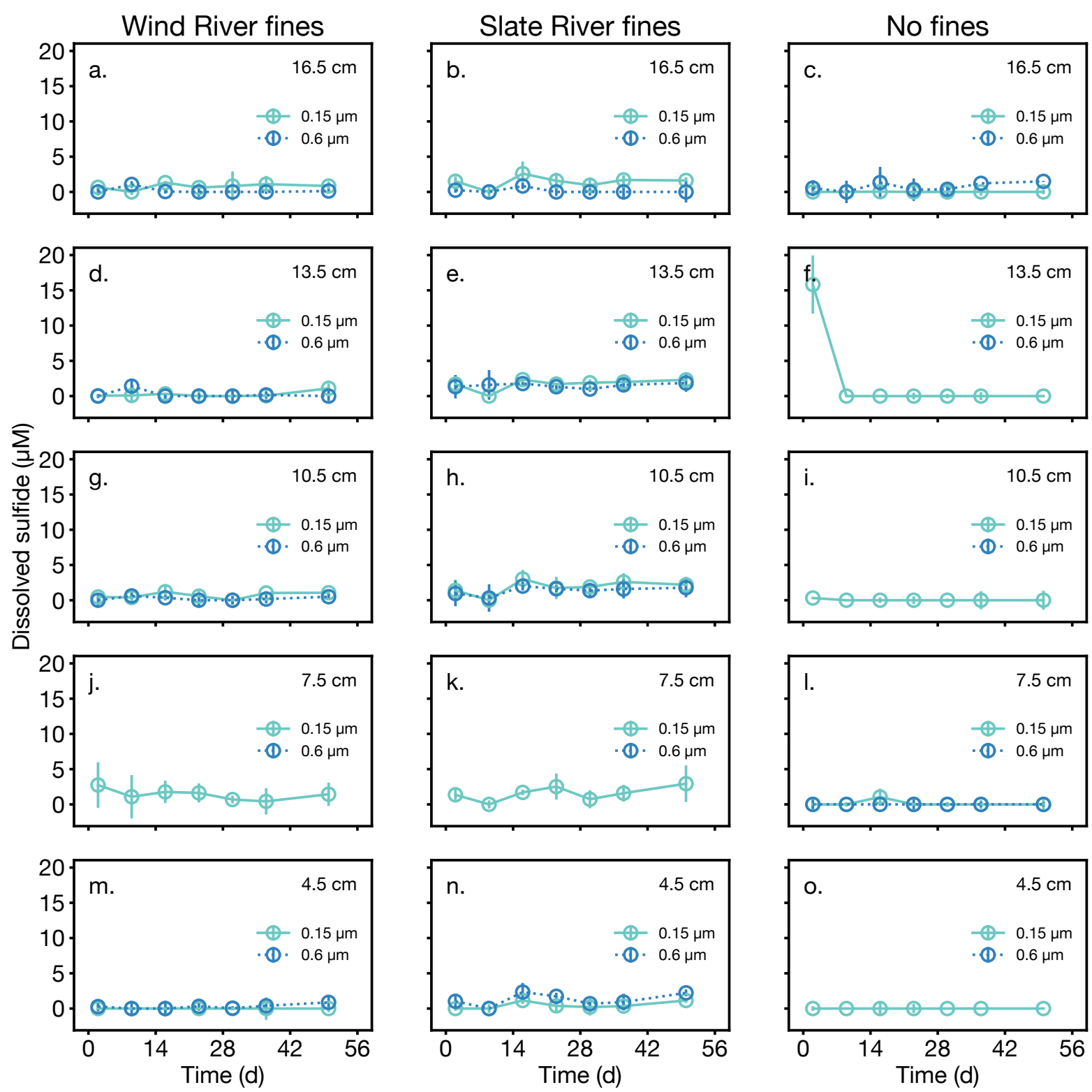

Figure S5 Dissolved sulfide concentrations during groundwater flow through columns with embedded lenses from Wind River (left) and Slate River (middle) and control columns without fines (right). Concentrations were determined on porewater extracted at $4.5-16.5 \mathrm{~cm}$ (lenses were located at $7.5 \mathrm{~cm}$ ) through rhizon samplers with mesh sizes of 0.15 and $0.60 \mu \mathrm{m}$. Error bars represent standard deviations between measurements on triplicate (Wind River and Slate River) duplicate (control) columns. Note that the $y$ axis scaling was chosen to show variations at low sulfide concentrations. The initial value in control columns at $13.5 \mathrm{~cm}(16 \pm 4 \mu \mathrm{M})$ likely represents an outlier. 

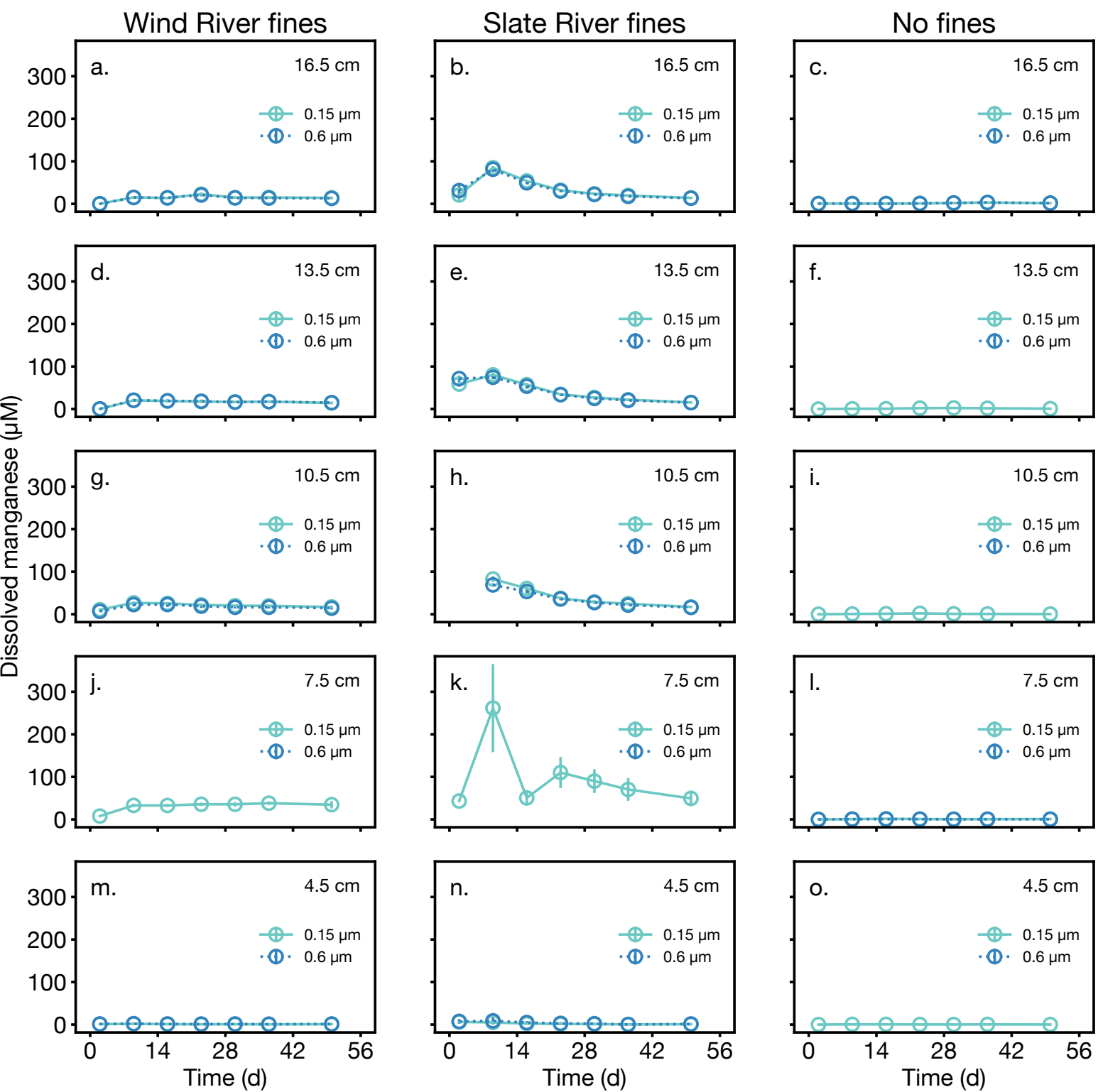

Figure S6 Dissolved manganese concentrations during groundwater flow through columns with embedded lenses from Wind River (left) and Slate River (middle) and control columns without fines (right). Concentrations were determined on porewater extracted at $4.5-16.5 \mathrm{~cm}$ (lenses were located at $7.5 \mathrm{~cm}$ ) through rhizon samplers with mesh sizes of 0.15 and $0.60 \mu \mathrm{m}$. Error bars represent standard deviations between measurements on triplicate (Wind River and Slate River) duplicate (control) columns. 

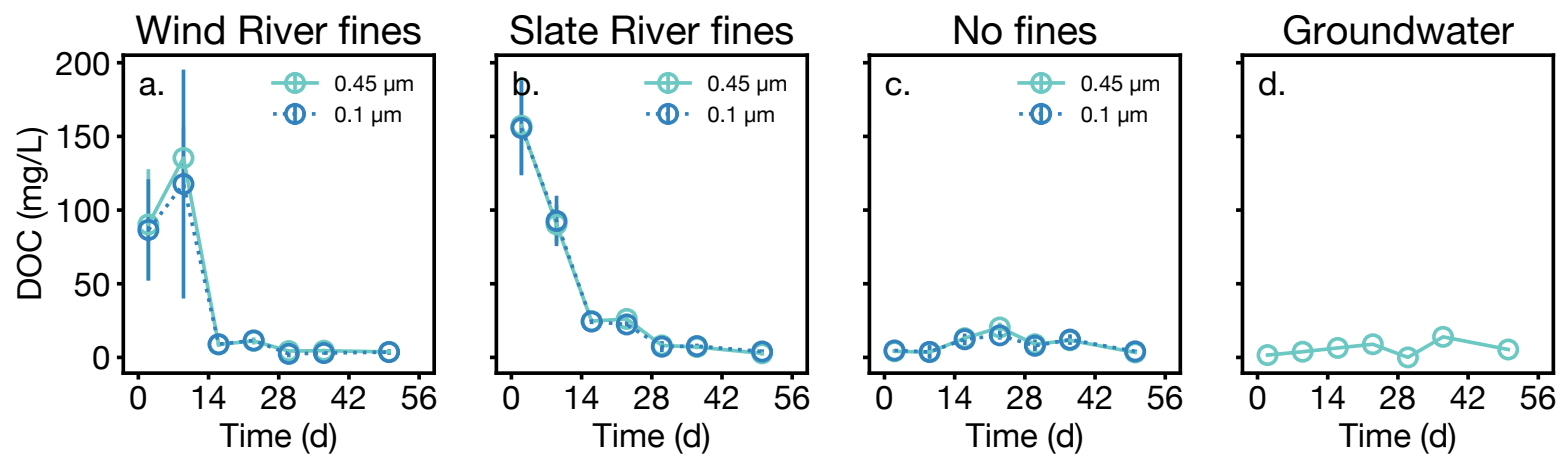

Figure S7 Dissolved organic carbon (DOC) concentrations in the effluent groundwater of columns with embedded lenses from Wind River (a.) and Slate River (b.), control columns without fines (c.), and in the inflowing groundwater. Concentrations were determined on samples passed through filters with mesh sizes of 0.45 and $0.1 \mu \mathrm{m}$. Error bars represent standard deviations between measurements on triplicate (Wind River and Slate River) duplicate (control) columns.
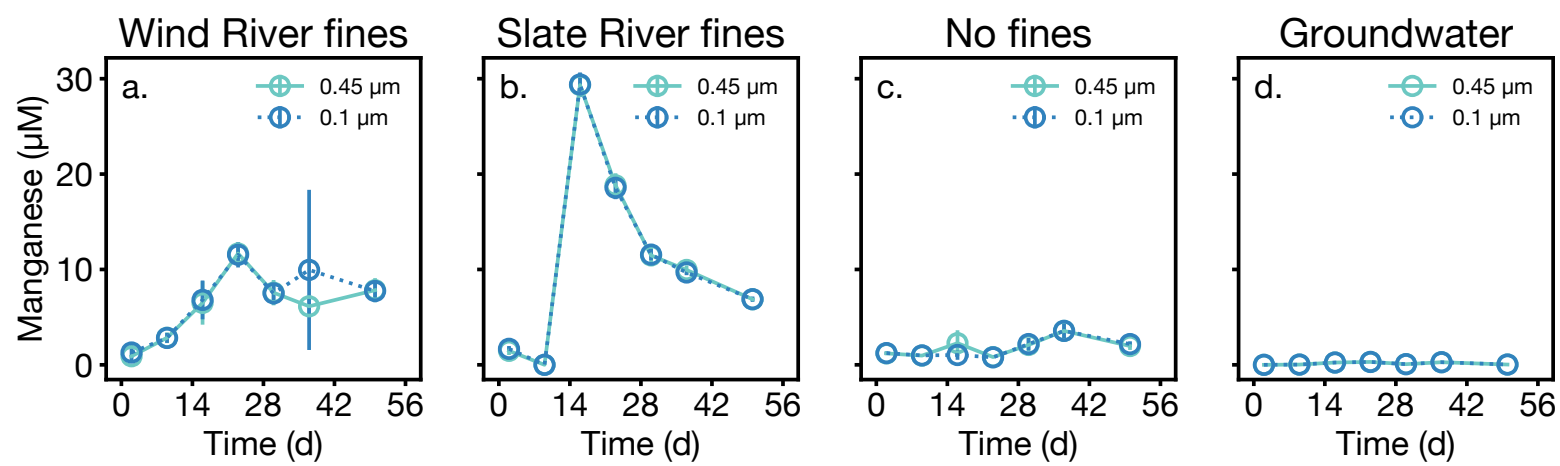

Figure S8 Dissolved manganese concentrations in the effluent groundwater of columns with embedded lenses from Wind River (a.) and Slate River (b.), control columns without fines (c.), and in the inflowing groundwater. Concentrations were determined on samples passed through filters with mesh sizes of 0.45 and $0.1 \mu \mathrm{m}$. Error bars represent standard deviations between measurements on triplicate (Wind River and Slate River) duplicate (control) columns. The large error bar in panel a at $37 \mathrm{~d}$ reflects unusually high concentrations measured in one of the triplicate columns; this was likely caused by an issue with that particular sample. 


\section{S6 Results end point sampling}
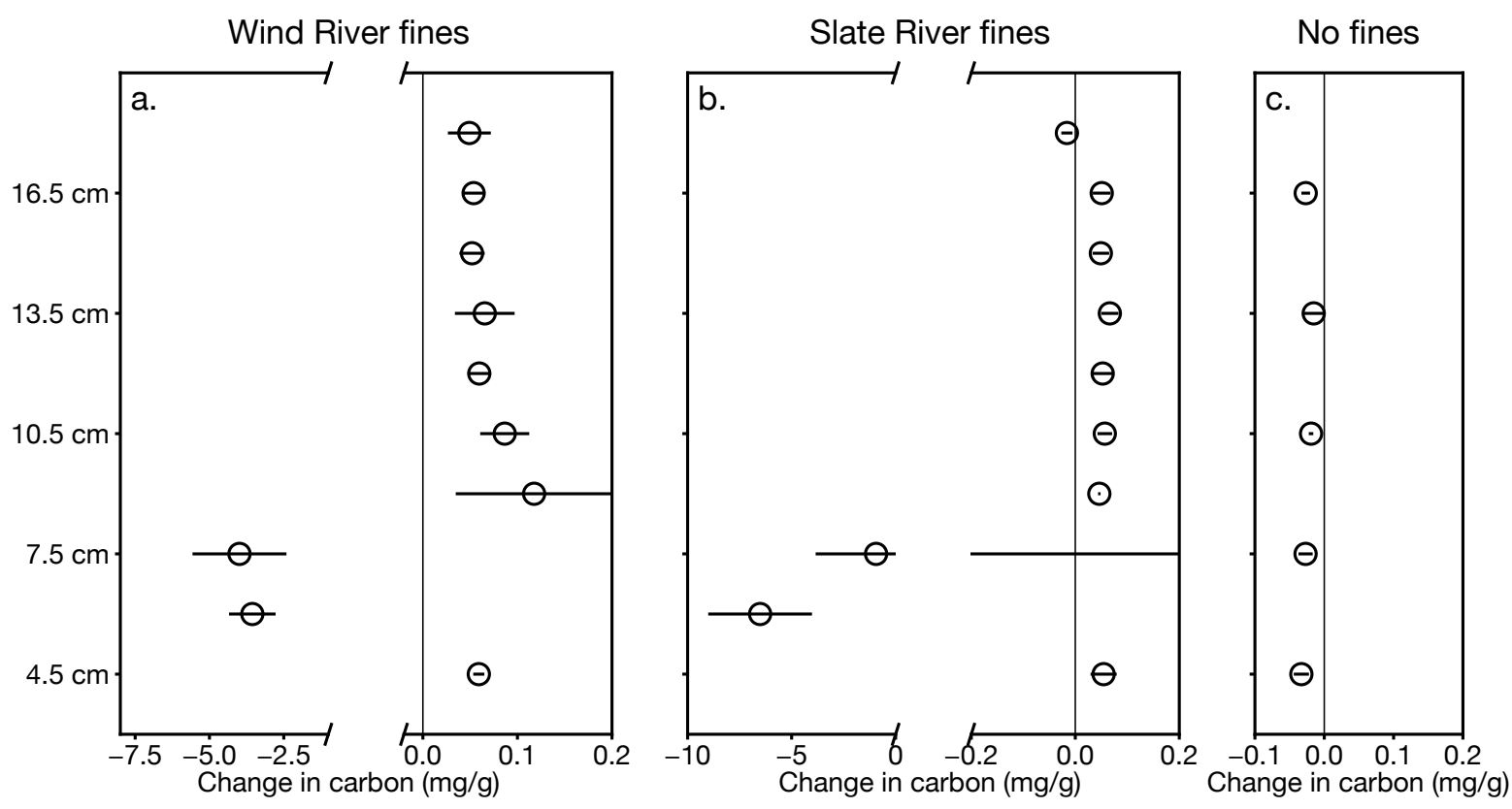

Figure S9 Change in total organic carbon between the start- and end point of the groundwater flow experiment across columns equipped with fines from a. Wind River and $\mathbf{b}$. Slate River and $\mathbf{c}$. control columns without fines. Initial measurements were performed on ferrihydrite-coated sand, and native Wind River and Slate River sediments and end point measurements are shown in Figure 2 in the main manuscript. Error bars represent standard deviations between measurements on triplicate (Wind River and Slate River) or duplicate (control) columns. 

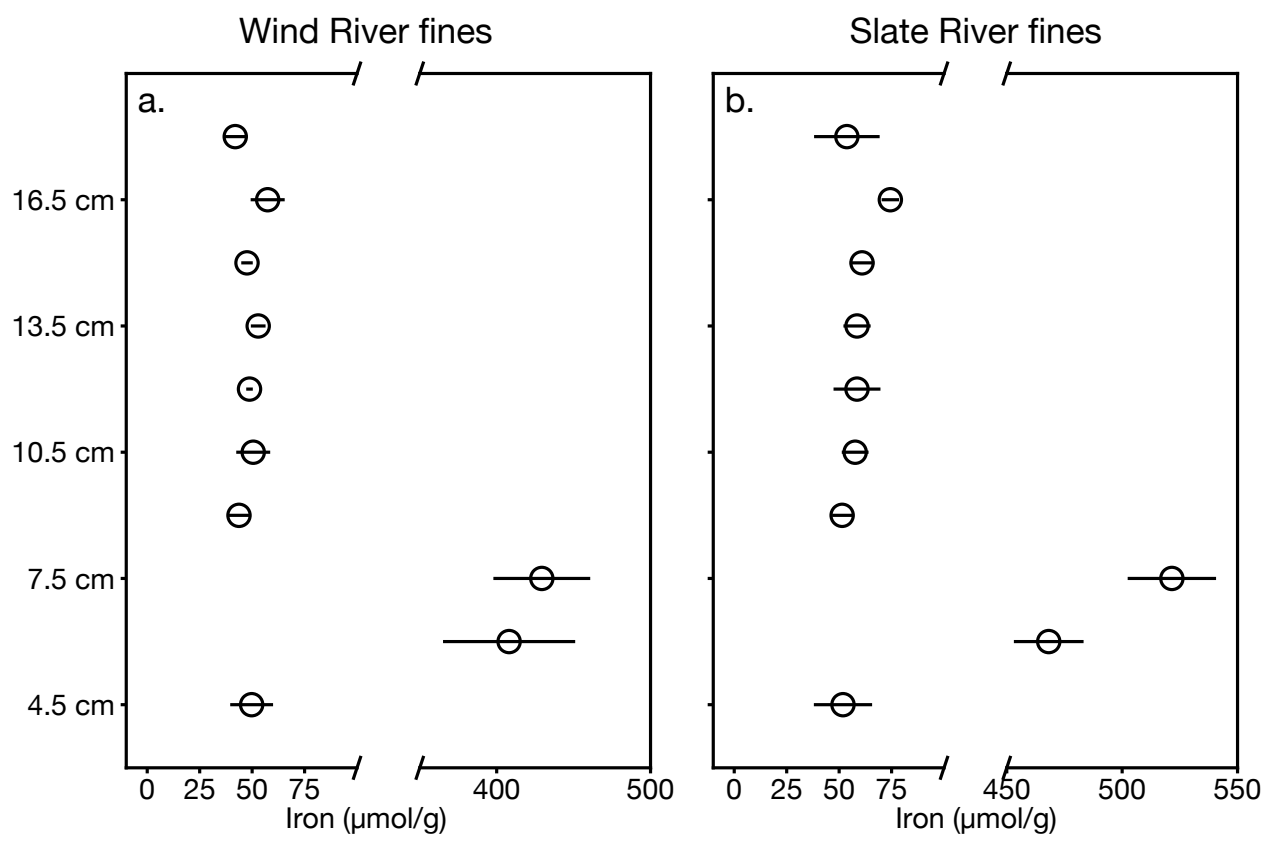

No fines

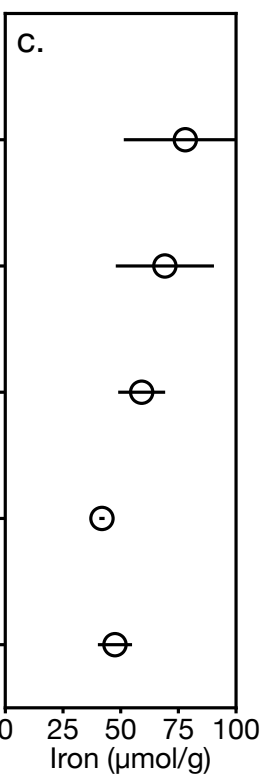

Figure S10 Variation in total iron at the end point of the experiment across columns equipped with fines from a. Wind River and b. Slate River and c. control columns without fines. Error bars represent standard deviations between measurements on triplicate (Wind River and Slate River) or duplicate (control) columns.
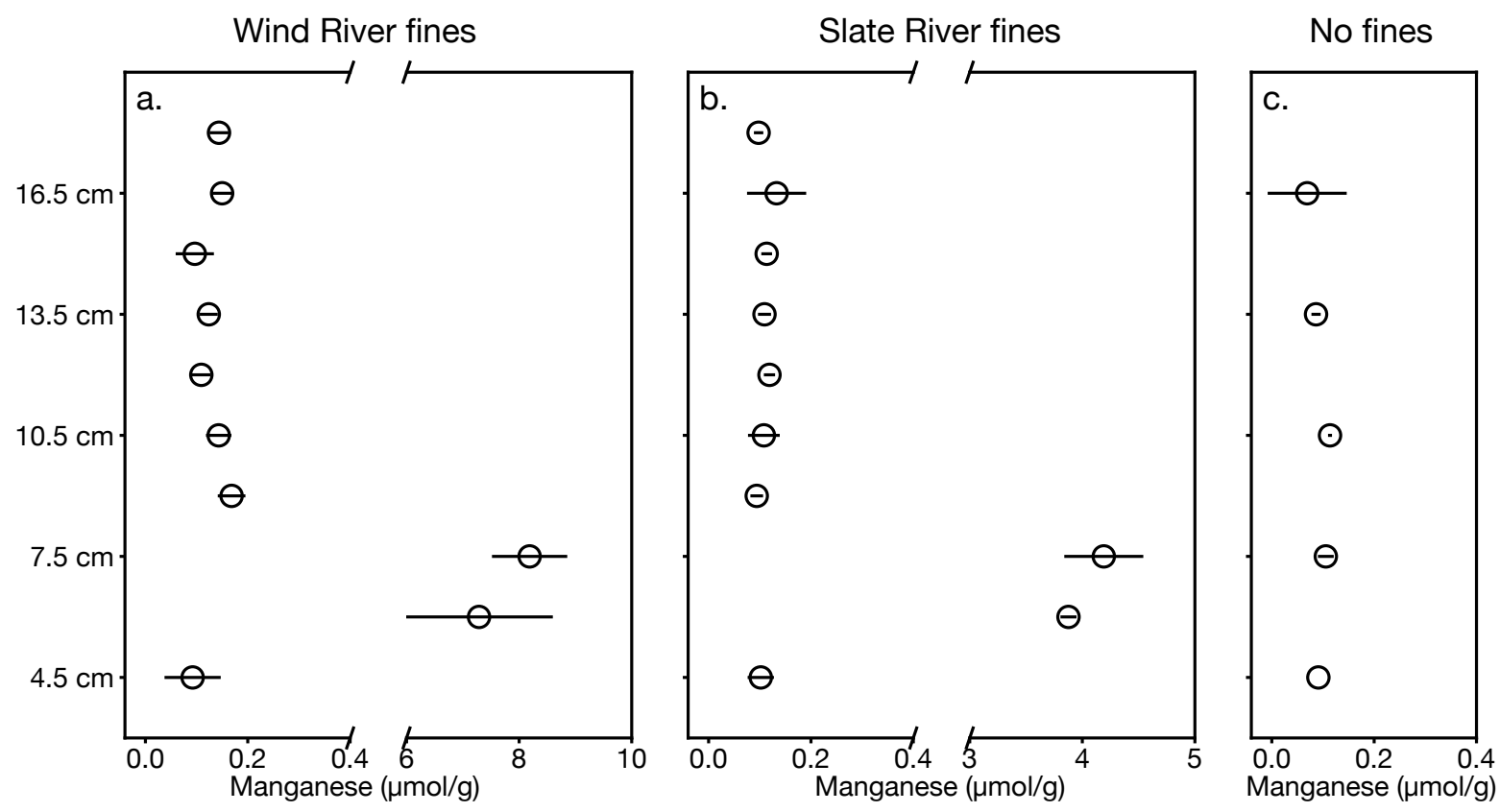

Figure S11 Variation in total manganese across columns equipped with fines from a. Wind River and $\mathbf{b}$. Slate River and $\mathbf{c}$. control columns without fines. Error bars represent standard deviations between measurements on triplicate (Wind River and Slate River) or duplicate (control) columns. 

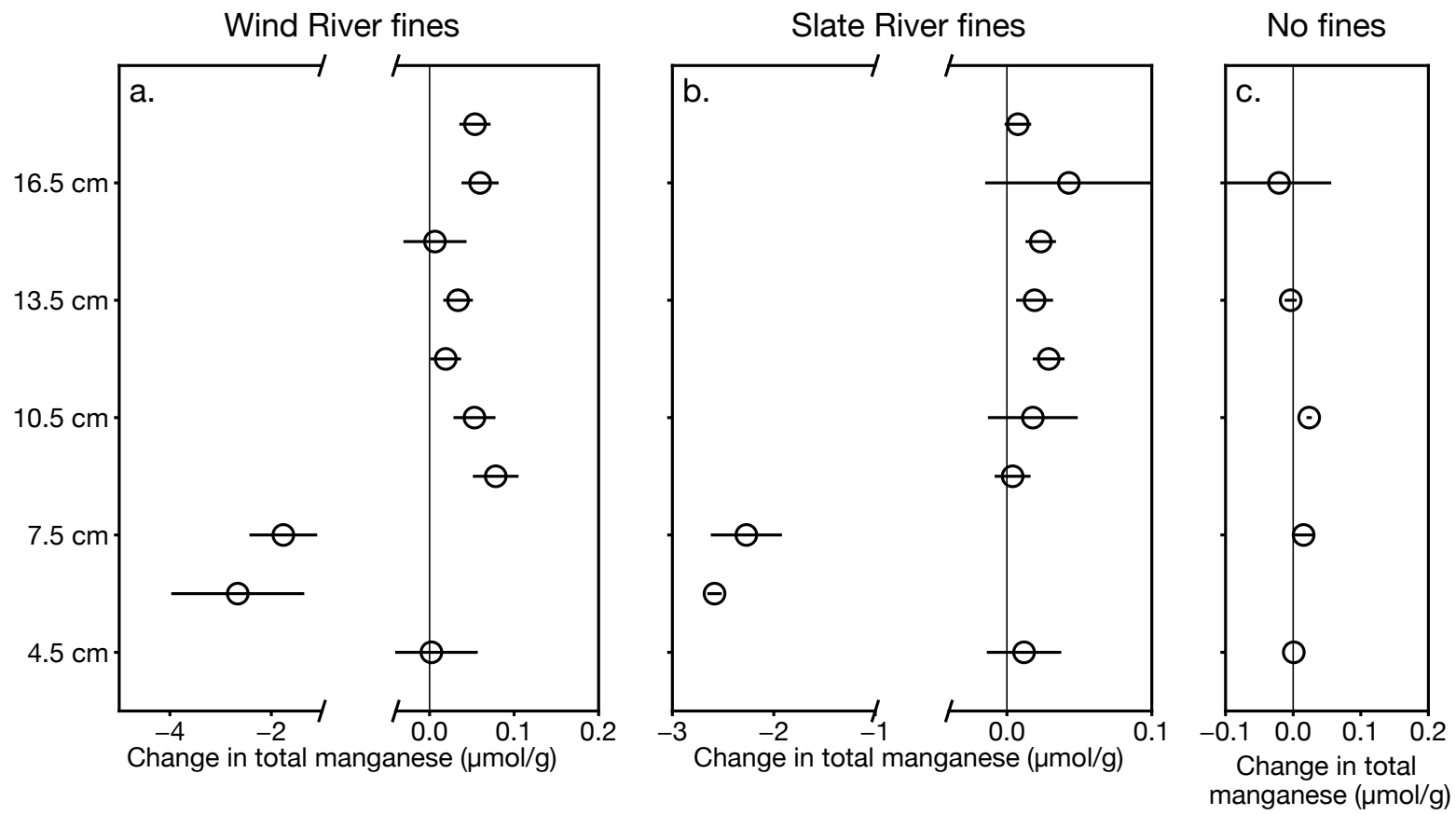

Figure S12 Change in total manganese between the start- and end point of the groundwater flow experiment across columns equipped with fines from a. Wind River and b. Slate River and c. control columns without fines. Initial measurements were performed on ferrihydrite-coated sand, and native Wind River and Slate River sediments and end point measurements are shown in Fig. S11. Error bars represent standard deviations between measurements on triplicate (Wind River and Slate River) or duplicate (control) columns.
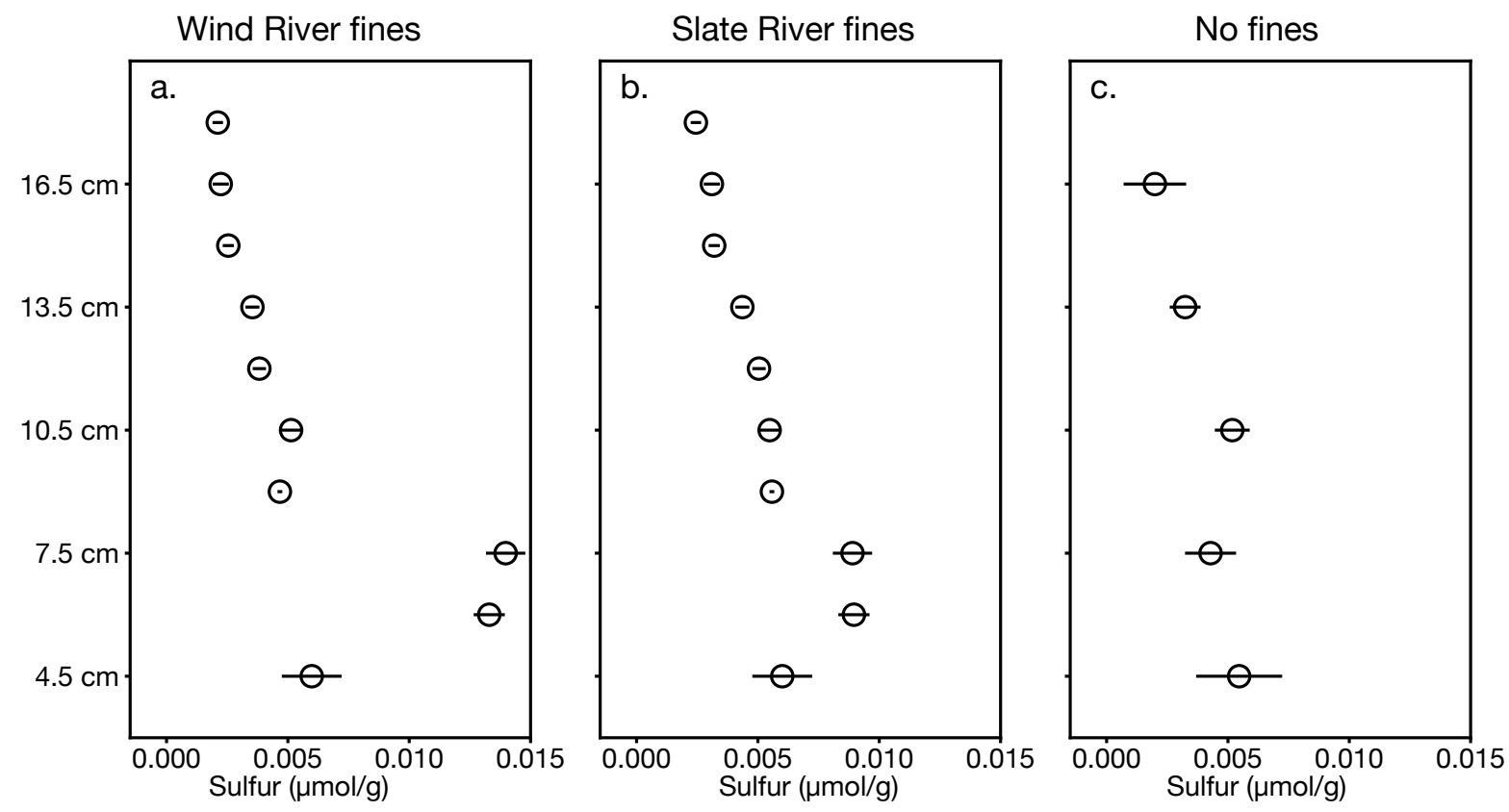

Figure S13 Variation in total sulfur across columns equipped with fines from $\mathbf{a}$. Wind River and $\mathbf{b}$. Slate River and c. control columns without fines. Error bars represent standard deviations between measurements on triplicate (Wind River and Slate River) or duplicate (control) columns. 

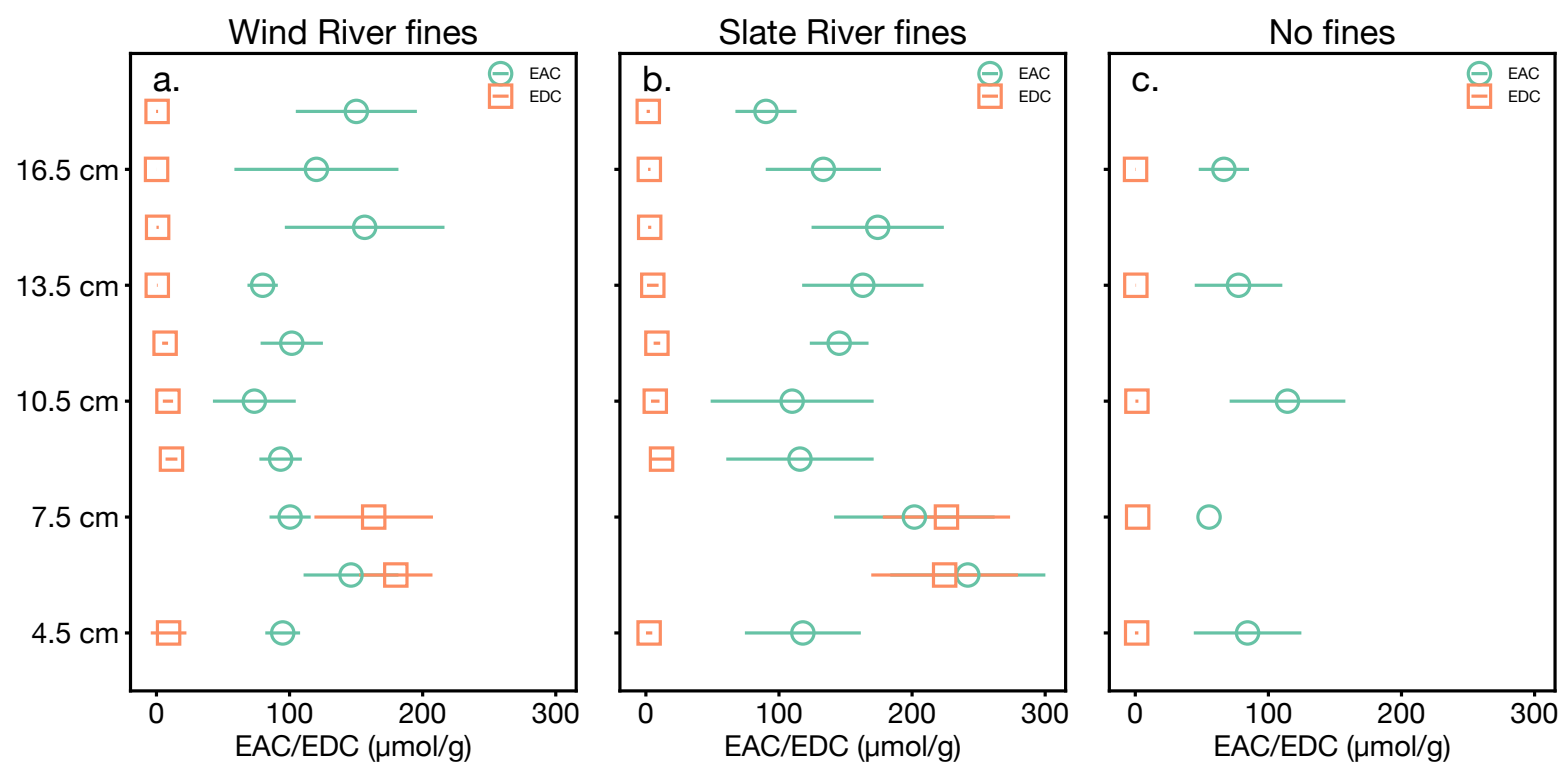

Figure S14 Variation in electron accepting capacities (EAC) and electron donating capacities (EDC) across columns equipped with fines from $\mathbf{a}$. Wind River and $\mathbf{b}$. Slate River and $\mathbf{c}$. control columns without fines. Error bars represent standard deviations between measurements on triplicate (Wind River and Slate River) or duplicate (control) columns.
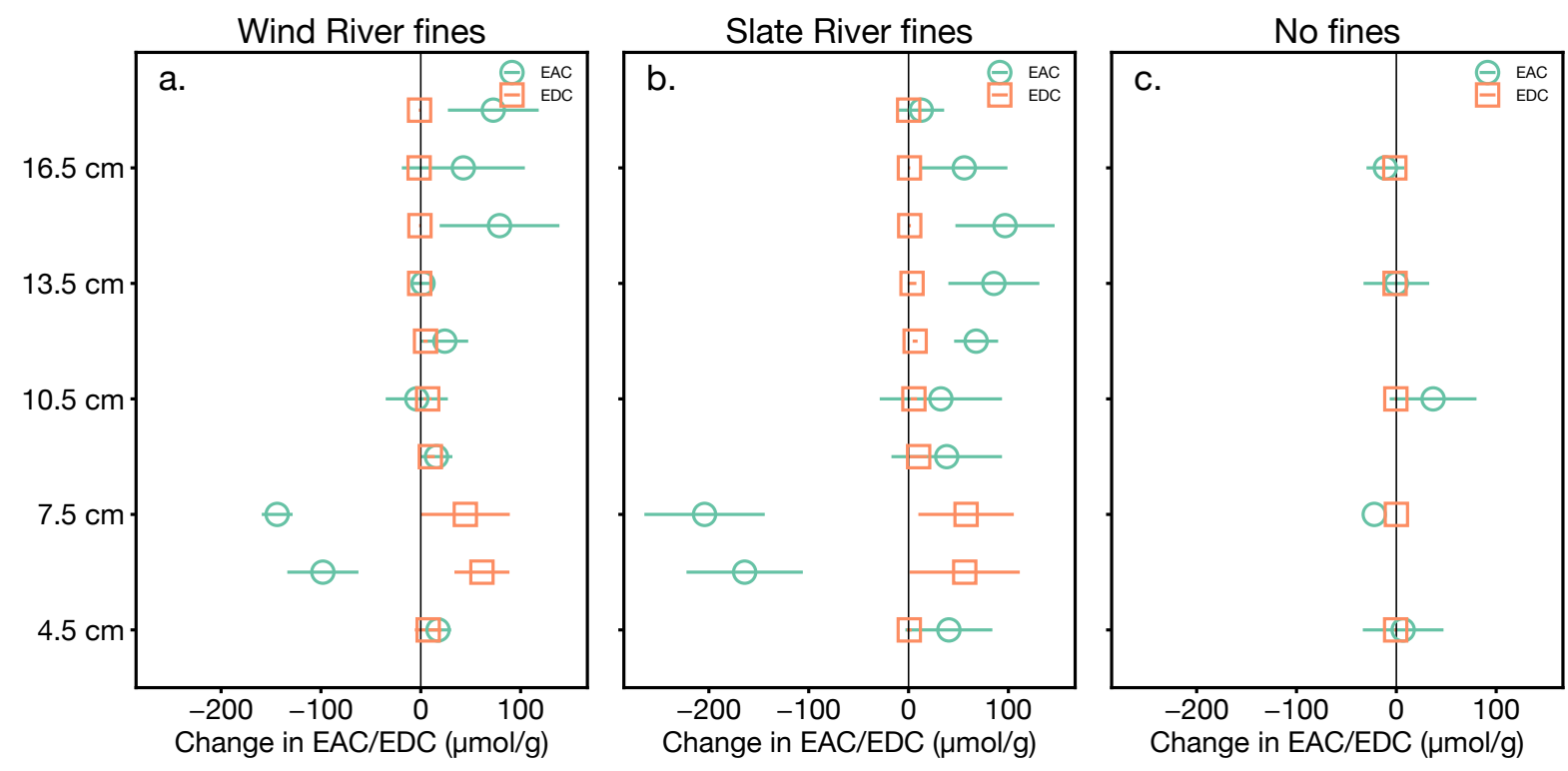

Figure S15 Change in electron accepting capacities (EAC) and electron donating capacities (EDC) between the start- and end point of the groundwater flow experiment across columns equipped with fines from a. Wind River and $\mathbf{b}$. Slate River and c. control columns without fines. Initial measurements were performed on ferrihydrite-coated sand, and native Wind River and Slate River sediments and end point measurements are shown in Fig. S14. Error bars represent standard deviations between measurements on triplicate (Wind River and Slate River) or duplicate (control) columns. 


\section{S7 Mass balance calculations for organic carbon}

We calculated the mass balance for organic carbon (OC) to assess the export of particulate OC from the Wind River and Slate River sediment lenses into the ferrihydrite-coated sand during groundwater flow. The mass balance for $\mathrm{OC}$ is given in equation $\mathrm{S} 1$ :

$$
\mathrm{n}_{\mathrm{OC}}\left(t_{0}\right)=\mathrm{n}_{\mathrm{OC} \text { lens }}\left(t_{\text {end }}\right)+\mathrm{n}_{\mathrm{OC} \text { sand }}\left(t_{\text {end }}\right)+\mathrm{n}_{\mathrm{OC} \text { effluent }}+\mathrm{n}_{\mathrm{OC} \text { resp }}
$$

where $\mathrm{n}_{\mathrm{OC}}\left(t_{0}\right)$ are the moles of OC present in the entire column at the onset $\left(t_{0}\right)$ of the experiment, $\mathrm{n}_{\mathrm{OC} \text { lens }}\left(t_{\text {end }}\right)$ and $\mathrm{n}_{\mathrm{OC} \text { sand }}\left(t_{\text {end }}\right)$ are the moles of $\mathrm{OC}$ in the lens and the sand at the end point $\left(t_{\text {end }}\right)$ of the experiment, $\mathrm{n}_{\mathrm{OC}}$ effluent are the moles of $\mathrm{OC}$ exported from the columns with the groundwater during the experiment, and $\mathrm{n}_{\mathrm{OC}}$ resp are the moles of $\mathrm{OC}$ respired by microorganisms during the experiment. Note that $\mathrm{n}_{\mathrm{OC}}$ respiration could not be measured in our setup which is why we estimated this term from the known other terms in the equation.

To determine the moles of $\mathrm{OC}$ in the lens and sand at $t_{0}$ and $t_{\text {end }}$ and in the effluent, we split the columns into ten slices as shown in Fig. S16 and assumed that (i) the lens filled slices 2 and 3 from the bottom while the remaining slices were made up of sand, and (ii) that $\mathrm{OC}$ was evenly distributed in all slices.

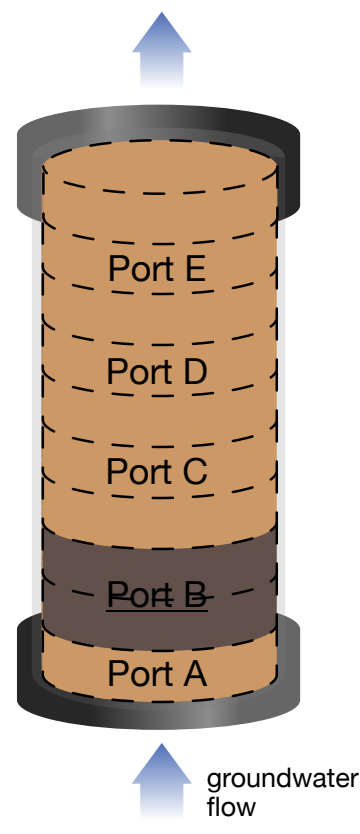

Figure S16 Schematic illustration of column slices used for carbon mass balance calculations. Light brown symbolizes sand and dark brows symbolizes sediment materials.

Using this approach, we calculated $\mathrm{n}_{\mathrm{OC}}\left(t_{0}\right)(\mathrm{mmol} \mathrm{C})$ according to equation $\mathrm{S} 2$

$$
\mathrm{n}_{\mathrm{OC}}\left(t_{0}\right)=\frac{f_{\mathrm{OC} \text { lens }} \cdot 10 \cdot m_{\text {lens }}}{\mathrm{M}_{\mathrm{w} \mathrm{C}}}+\frac{f_{\mathrm{OC} \text { sand }} \cdot 10 \cdot m_{\mathrm{sand}}}{\mathrm{M}_{\mathrm{w} \mathrm{C}}}
$$

where $f_{\mathrm{OC}}$ lens is the weight percentage of $\mathrm{OC}$ in the lens ( $f_{\mathrm{OC} \text { lens }} \cdot 10$ equals $\mathrm{mg} \mathrm{C} / \mathrm{g}$ lens), $m_{\text {lens }}$ is the dry mass of the lens (in $\mathrm{g}$, Table $\mathrm{S} 5$ ), and $\mathrm{M}_{\mathrm{w}}, \mathrm{C}$ is the molar mass of carbon (12.011 $\mathrm{g} / \mathrm{mol}$ ). We determined $\mathrm{n}_{\mathrm{OC}}$ lens $\left(t_{\text {end }}\right)$ and $\mathrm{n}_{\mathrm{OC}}$ sand $\left(t_{\text {end }}\right)$ (both in mmole $\mathrm{C}$ ) from the sum of 
OC in each slice according to equation S3:

$$
\mathrm{n}_{\mathrm{OC} \text { lens }}\left(t_{\text {end }}\right)+\mathrm{n}_{\mathrm{OC} \text { sand }}\left(t_{\text {end }}\right)=\sum_{n=1}^{10} \frac{f_{\mathrm{OC} \text { slice } \mathrm{n}} \cdot 10 \cdot m_{\text {slice } \mathrm{n}}}{\mathrm{M}_{\mathrm{w} \mathrm{C}}}
$$

where $n$ refers to the slice number starting from the bottom of the column, $f_{\mathrm{OC}}$ slice $\mathrm{n}$ is the weight percentage of $\mathrm{OC}$ in slice $n$ ( $f_{\mathrm{OC}}$ slice $\mathrm{n} \cdot 10$ equals $\mathrm{mg} \mathrm{C} / \mathrm{g}$ sand), and $m_{\text {slice } \mathrm{n}}$ is the dry mass of slice $n$ (in $g$, calculated from the total mass of sand in the column given in Table S5).

$\mathrm{n}_{\mathrm{OC} \text { effluent }}(\mathrm{mmol} \mathrm{C}$ ) was determined by integrating dissolved organic carbon (DOC) concentrations in the effluent $\left(\mathrm{C}_{\mathrm{DOC}}\right.$ effluent in $\mathrm{g} \mathrm{C} / \mathrm{L}$, Fig. $\left.\mathrm{S} 7\right)$ from $t_{0}$ to $t_{\text {end }}$ using equation S4:

$$
\mathrm{n}_{\mathrm{OC} \text { effluent }}=\int_{t_{0}}^{t_{\text {end }}} \frac{\mathrm{C}_{\mathrm{DOC} \text { effluent }} \cdot \mathrm{Q}}{\mathrm{M}_{\mathrm{w} \mathrm{C}}} d t
$$

where $\mathrm{Q}$ is the flow rate $(\mathrm{mL} / \mathrm{d})$, and $t$ is time in days.

Table S5 Dry mass of ferrihydrite-coated sand and sediment materials in columns embedded with fines from Wind River (RV1-3), Slate River (SR1-3), and control columns without fines (CT1-2).

\begin{tabular}{lcc}
\hline Column & Dry mass sand $(\mathrm{g})$ & Dry mass lens $(\mathrm{g})$ \\
\hline RV1 & 1312.90 & 64.76 \\
RV2 & 1312.75 & 70.60 \\
RV3 & 1303.96 & 72.77 \\
SR1 & 1326.71 & 47.19 \\
SR2 & 1324.68 & 48.51 \\
SR3 & 1315.70 & 55.06 \\
CT1 & 1361.31 & \\
CT2 & 1315.31 & \\
\hline
\end{tabular}




\section{S8 Microbial analysis}

We determined the absolute abundance of bacterial and archaeal 16S rRNA genes and Geobacteraceae-specific citrate synthase ( $g l t A)$ genes by droplet digital PCR. Primers used to quantify the 16S rRNA genes (for both Bacteria and Archaea) were Uni340F and Uni806R(2), whereas gltA genes were amplified using the primers CS375nF and CS598nR(3). Primer concentration, PCR conditions, and template dilution were optimized in trial runs. For both target genes, PCR reactions were performed in $25 \mu \mathrm{L}$ volumes containing: $12.5 \mu \mathrm{L}$ EvaGreen $\mathbb{R}$ SuperMix, $9 \mu \mathrm{L}$ nuclease-free water, $0.5 \mu \mathrm{L}$ bovine serum albumin $(2.5 \mathrm{mg} / \mathrm{mL}), 1 \mu \mathrm{L}$ of forward and reverse primers $(5 \mu \mathrm{M})$, and $1 \mu \mathrm{L}$ of DNA template. The DNA template was diluted 1:1000 for $16 \mathrm{~S}$ rRNA and 1:10 for gltA for each sample in nuclease-free water. A portion of the reaction mixture $(20 \mu \mathrm{L})$ was emulsified using the Bio-Rad QX200TM Droplet Generator (Bio-Rad, Hercules, $\mathrm{CA})$. The resulting emulsion $(38 \mu \mathrm{L})$ was transferred to a 96 -well plate, sealed, and run through PCR on a Bio-Rad T100 Thermocycler. The amplification conditions were as follows: 5 min at $95^{\circ} \mathrm{C}$; 45 cycles of $1 \mathrm{~min}$ at $95^{\circ} \mathrm{C}, 1 \mathrm{~min}$ at $52^{\circ} \mathrm{C}$, and $1 \mathrm{~min}$ at $72^{\circ} \mathrm{C}$. Enzymes were deactivated by a 5 min hold at $4^{\circ} \mathrm{C}$, followed by a 5 min hold at $90^{\circ} \mathrm{C}$. For each primer set, all samples were run on a single plate and included a no-template control (nuclease free water) and a positive control. Droplets were read on a Bio-Rad QX200 Droplet Reader. All wells had at least 12,000 accepted droplets. For both genes, the positive droplet threshold was set manually. For the $16 \mathrm{~S}$ rRNA assay, the positive droplet threshold was set within each sample to accurately match the binomial distribution of droplets. For the gltA assay, the same threshold was applied to all samples. All droplet analysis was performed using the QuantaSoftTM Analysis Pro software (Bio-Rad, Hercules, CA). Gene abundance (copies per $\mu \mathrm{L}$ ) was corrected to account for the initial dilution of DNA template and reaction volume reduction to allow for emulsification. Finally, we converted this corrected abundance to copies per $\mathrm{g}$ sand by multiplying by the elution volume, and then dividing by the recorded weight of sample material used in each extraction (in g). 

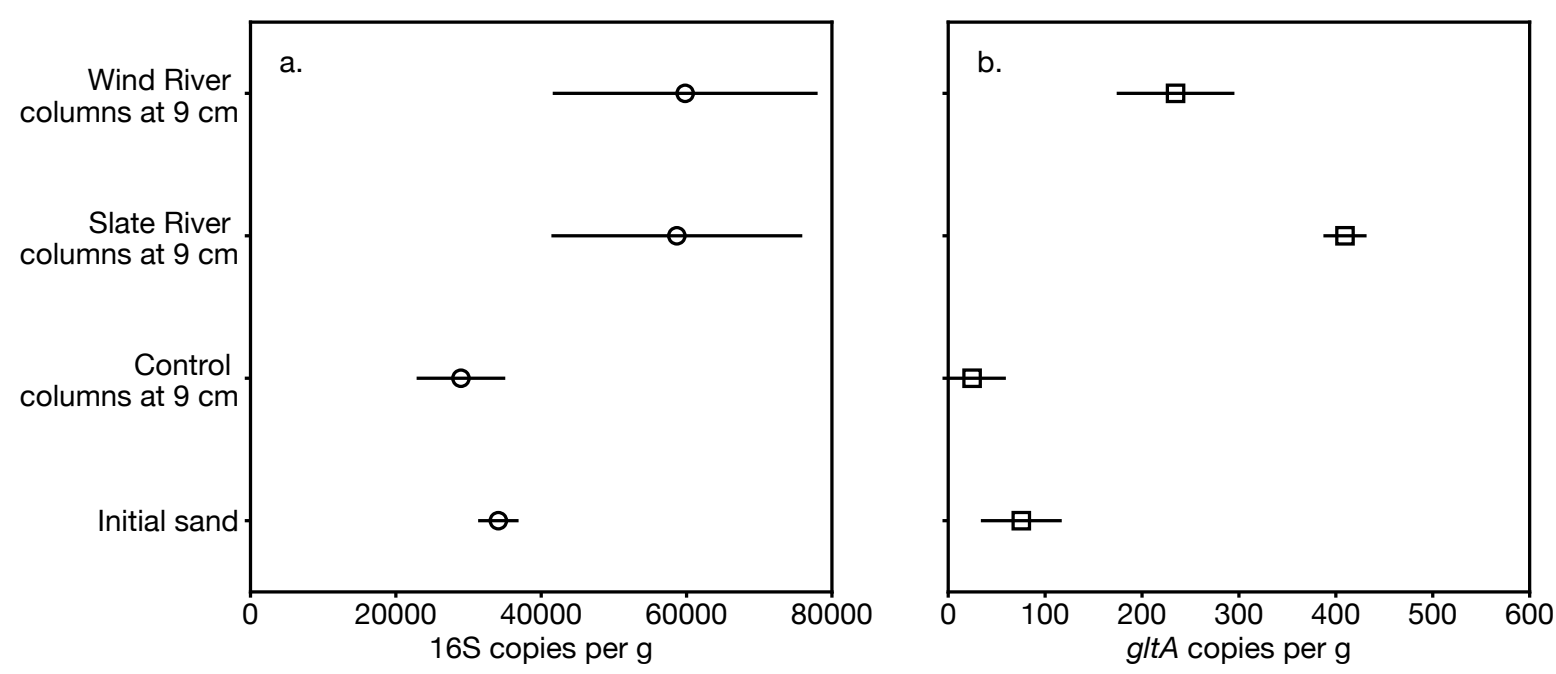

Figure S17 Gene copies in columns with fines from Wind River and Slate River, in control columns without embedded fines, and in the initial sand. Gene copies of a. 16S rRNA and $\mathbf{b}$. gt/A per $\mathrm{g}$ of sand are shown for selected samples collected from one of the Wind River, one of the Slate River and one of the control columns at the end point of the groundwater flow experiment $9 \mathrm{~cm}$ downstream of the groundwater inlet. Gene copies are also shown for an initial sand sample. Error bars represent deviations between duplicate measurements on single samples. 


\section{S9 Mass balance calculations for iron}

The mass balance for total iron ( $\mathrm{Fe}$ ) was calculated according to equations (all terms in mmol $\mathrm{Fe}) \mathrm{S} 5-\mathrm{S} 8$ :

$$
\mathrm{n}_{\mathrm{Fe}}\left(t_{0}\right)=\mathrm{n}_{\mathrm{Fe} \text { lens }}\left(t_{\text {end }}\right)+\mathrm{n}_{\mathrm{Fe} \mathrm{sand}}\left(t_{\text {end }}\right)+\mathrm{n}_{\mathrm{Fe} \text { dissolved effluent }}+\mathrm{n}_{\mathrm{Fe} \text { colloid effluent }}
$$

where $\mathrm{n}_{\mathrm{Fe}}\left(t_{0}\right)$ are the moles of total Fe present in the entire column at the onset $\left(t_{0}\right)$ of the experiment, $\mathrm{n}_{\mathrm{Fe}}$ lens $\left(t_{\text {end }}\right)$ and $\mathrm{n}_{\mathrm{Fe} \text { sand }}\left(t_{\text {end }}\right)$ are the moles of total $\mathrm{Fe}$ in the lens and in the sand at the end $\left(t_{\text {end }}\right)$ of the experiment, $\mathrm{n}_{\mathrm{Fe}}$ dissolved effluent and $\mathrm{n}_{\mathrm{Fe}}$ colloid effluent are the moles of total Fe exported from the columns with the groundwater as dissolved or particulate species during the experiment. Note that $n_{F e}$ colloid effluent could not be measured in our setup which is why we estimated this term from the known other terms in the equation.

$$
\mathrm{n}_{\mathrm{Fe}}\left(t_{0}\right)=\frac{f_{\mathrm{Fe} \text { lens }} \cdot 10 \cdot m_{\text {lens }}}{\mathrm{M}_{\mathrm{w} \mathrm{C}}}+\frac{f_{\mathrm{Fe} \mathrm{sand}} \cdot 10 \cdot m_{\text {sand }}}{\mathrm{M}_{\mathrm{w} \mathrm{Fe}}}
$$

where $f_{\mathrm{Fe}}$ lens is the weight percentage of $\mathrm{Fe}$ in the lens $\left(f_{\mathrm{Fe}}\right.$ lens 10 equals $\mathrm{mg} \mathrm{Fe} / \mathrm{g}$ lens $), m_{\text {lens }}$ is the dry mass of the lens (in $\mathrm{g}$, Table S5), and $\mathrm{M}_{\mathrm{w}}, \mathrm{Fe}$ is the molar mass of carbon $(55.845 \mathrm{~g} / \mathrm{mol}$ ).

$$
\mathrm{n}_{\mathrm{Fe} \text { lens }}\left(t_{\text {end }}\right)+\mathrm{n}_{\mathrm{Fe} \mathrm{sand}}\left(t_{\text {end }}\right)=\sum_{n=1}^{10} \frac{f_{\mathrm{Fe} \mathrm{slice} \mathrm{n}} \cdot 10 \cdot m_{\text {slice } \mathrm{n}}}{\mathrm{M}_{\mathrm{w} \mathrm{Fe}}}
$$

where $n$ refers to the slice number starting from the bottom of the column, $f_{\text {Fe slice } n}$ is the weight percentage of Fe in slice $n\left(f_{\mathrm{Fe}}\right.$ slice $\mathrm{n} \cdot 10$ equals $\mathrm{mg} \mathrm{Fe} / \mathrm{g}$ sand $)$, and $m_{\text {slice } \mathrm{n}}$ is the dry mass of slice $n$ (in g, calculated from the total mass of sand in the column given in Table S5).

$$
\mathrm{n}_{\mathrm{Fe} \text { effluent }}=\int_{t_{0}}^{t_{\mathrm{end}}} \frac{\mathrm{C}_{\mathrm{Fe} \text { dissolved effluent }} \cdot \mathrm{Q}}{\mathrm{M}_{\mathrm{w} \text { Fe }}} d t
$$

where $\mathrm{C}_{\mathrm{Fe}}$ dissolved effluent $(\mathrm{g} \mathrm{Fe} / \mathrm{L})$ is the dissolved Fe concentrations in the effluent (data not shown), and $\mathrm{Q}$ is the flow rate $(\mathrm{mL} / \mathrm{d})$, and $t$ is time in days.

The redox state of $\mathrm{Fe}$ in each term in equation $\mathrm{S} 5$ was determined by multiplying the respective term with the ratio of electron accepting capacity (EAC) over electron exchanging capacity (EEC), EAC/EEC, for Fe(III) and by (1-EAC/EEC) for Fe(II) using data in Fig. S18 and EAC/EEC ratios of $0.97 \pm 0.02$ for the initial sand, $0.68 \pm 0.04$ for Wind River, and $0.70 \pm$ 0.03 for Slate River sediments. Results of the mass balance calculations are shown in Table S6. 
Table S6 Mass balance for iron in the columns with Wind River and Slate River fines at the onset $\left(t_{0}\right)$ and end $\left(t_{e n d}\right)$ of the groundwater flow experiment. Fe that was unaccounted for in the mass balance likely represented the particulate fraction $>0.45 \mu \mathrm{m}$ and was exported from the columns with the groundwater.

\begin{tabular}{lcc}
\hline Description & $\begin{array}{c}\text { Columns with } \\
\text { Wind River fines }\end{array}$ & $\begin{array}{c}\text { Columns with } \\
\text { Slate River fines }\end{array}$ \\
\hline $\mathrm{Fe}(\mathrm{III})$ in lens at $\mathrm{t}_{0}(\mathrm{mmol})$ & $22.3 \pm 1.3$ & $21.0 \pm 1.8$ \\
$\mathrm{Fe}(\mathrm{II})$ in lens at $\mathrm{t}_{0}(\mathrm{mmol})$ & $10.8 \pm 0.6$ & $8.7 \pm 0.7$ \\
$\mathrm{Fe}(\mathrm{III})$ in sand at $\mathrm{t}_{0}(\mathrm{mmol})$ & $75.8 \pm 0.3$ & $76.5 \pm 0.3$ \\
$\mathrm{Fe}(\mathrm{II})$ in sand at $\mathrm{t}_{0}(\mathrm{mmol})$ & $1.7 \pm 0.0$ & $1.7 \pm 0.0$ \\
\hline $\mathrm{Fe}(\mathrm{III})$ in lens at $\mathrm{t}_{\text {end }}(\mathrm{mmol})$ & $12.2 \pm 1.3$ & $12.3 \pm 1.9$ \\
$\mathrm{Fe}(\mathrm{II})$ in lens at $\mathrm{t}_{\text {end }}(\mathrm{mmol})$ & $16.9 \pm 0.8$ & $74.3 \pm 1.6$ \\
$\mathrm{Fe}(\mathrm{III})$ in sand at $\mathrm{t}_{\text {end }}(\mathrm{mmol})$ & $62.5 \pm 0.9$ & $2.9 \pm 0.4$ \\
$\mathrm{Fe}(\mathrm{II})$ in sand at $\mathrm{t}_{\text {end }}(\mathrm{mmol})$ & $3.1 \pm 1.1$ & $0.7 \pm 0.0$ \\
\hline $\mathrm{Fe}<0.45 \mu \mathrm{m}$ in effluent $(\mathrm{mmol})$ & $0.6 \pm 0.0$ & $5.1 \pm 0.1$ \\
$\mathrm{Fe}$ unaccounted for $(\mathrm{mmol})$ & $15.3 \pm 0.0$ & \\
\hline \hline
\end{tabular}
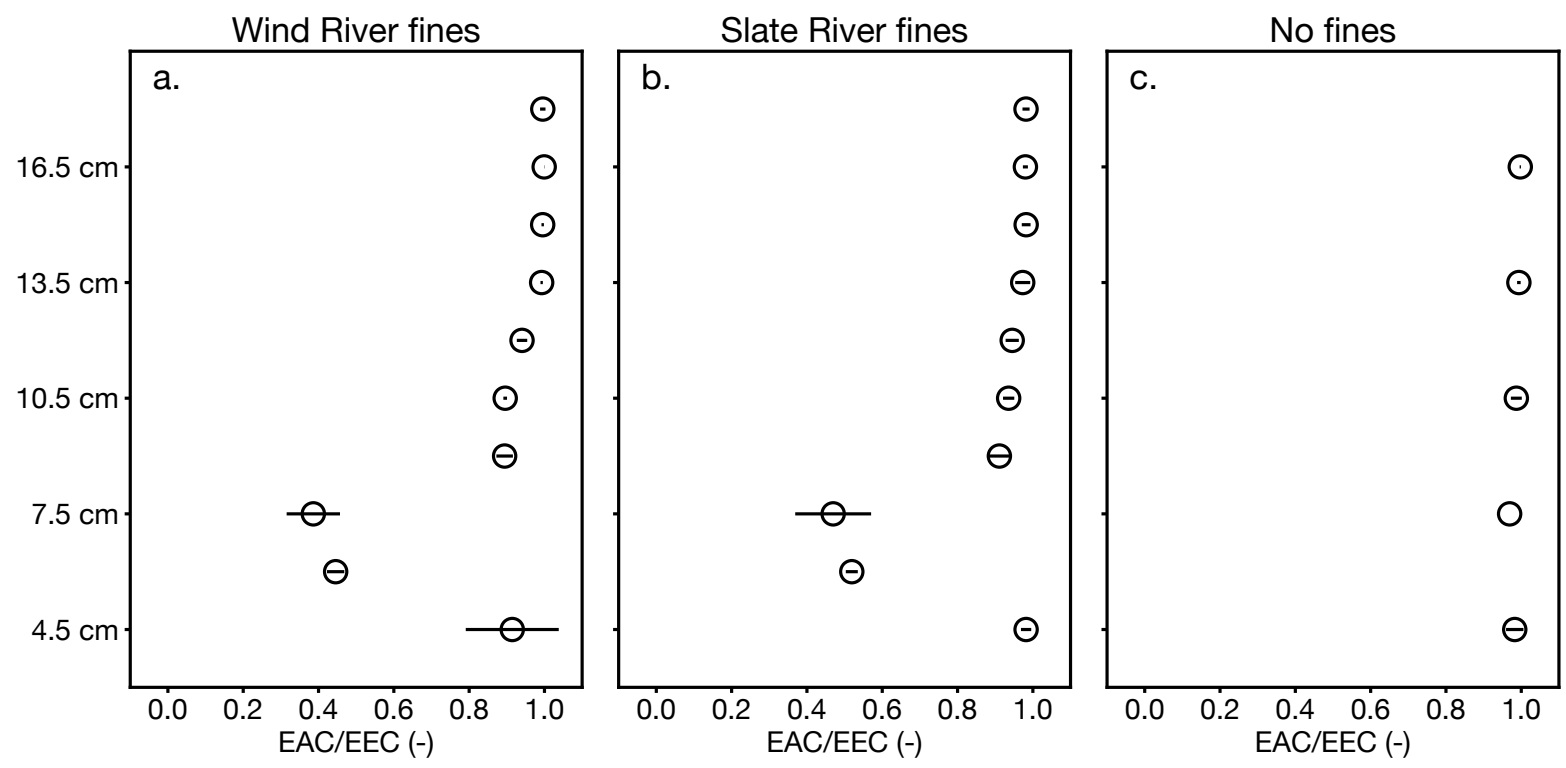

Figure S18 Variation in the fraction of electron accepting capacities (EAC) relative to the total exchanging capacity (EEC; sum of electron donating and accepting capacities) across columns equipped with fines from a. Wind River and $\mathbf{b}$. Slate River and c. control columns without fines. Error bars represent standard deviations between measurements on triplicate (Wind River and Slate River) duplicate (control) columns. 


\section{S10 Visual observations of changes in columns}
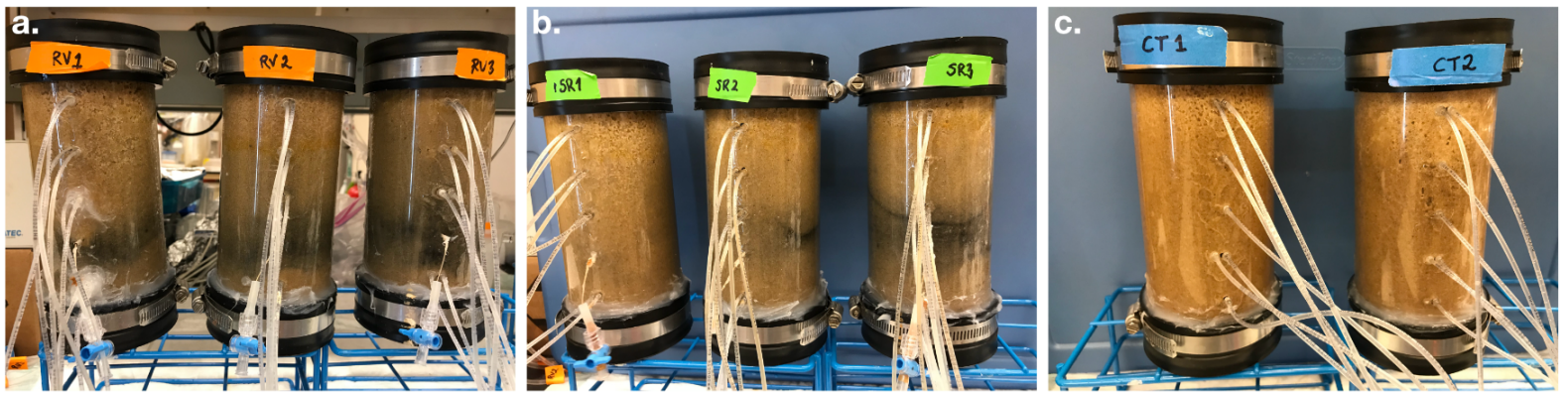

Figure S19 Photos of the columns with embedded fines from a. Wind River, b. Slate River and c. control columns without embedded fines taken at the end of the groundwater flow experiment. Notice the black coloration of the sand around ports B in columns with embedded fines.

\section{References}

[1] Kumar, N., Noël, V., Planer-Friedrich, B., Besold, J., Lezama-Pacheco, J., Bargar, J. R., Brown, G. E., Fendorf, S., and Boye, K. (2020) Redox Heterogeneities Promote Thioarsenate Formation and Release into Groundwater from Low Arsenic Sediments. Environmental Science \& Technology 54, 3237-3244.

[2] Takai, K., and Horikoshi, K. (2000) Rapid Detection and Quantification of Members of the Archaeal Community by Quantitative PCR Using Fluorogenic Probes. Applied and Environmental Microbiology 66, 5066-5072.

[3] Akob, D. M., Lee, S. H., Sheth, M., Küsel, K., Watson, D. B., Palumbo, A. V., Kostka, J. E., and Chin, K.-J. (2012) Gene Expression Correlates with Process Rates Quantified for Sulfateand Fe(III)-Reducing Bacteria in U(VI)-Contaminated Sediments. Frontiers in Microbiology 3, 280. 